\title{
Molecular cloning and characterization of KISS1 promoter and effect of KISS1 gene mutations on litter size in the goat
}

\author{
X.P. An, P. Han, J.X. Hou, H.B. Zhao, Y. Yan, T. Ma, F. Fang, \\ F.X. Meng, Y.X. Song, J.G. Wang and B.Y. Cao \\ College of Animal Science and Technology, Northwest A\&F University, \\ Yangling, Shaanxi, China
}

Corresponding author: B.Y. Cao

E-mail: caobinyun@yahoo.com.cn

Genet. Mol. Res. 12 (4): 4308-4316 (2013)

Received May 29, 2012

Accepted November 10, 2012

Published February 28, 2013

DOI http://dx.doi.org/10.4238/2013.February.28.13

\begin{abstract}
Kisspeptins, the product of the KISS1 gene, play an essential role in the regulation of reproductive functions, acting primarily at the hypothalamic level of the gonadotropic axis. We detected polymorphisms of the goat KISS1 gene in 723 individuals from three goat breeds (Xinong Saanen, Guanzhong, and Boer) by DNA pooling, PCR-RFLP, and DNA sequencing methods. We cloned the promoter sequence of this gene and found it to share high similarity with that of the bovine KISS1 promoter. Six TATA boxes were found in the goat KISS1 promoter region. Two novel SNPs (g.2124T>A and g.2270C $>$ T) were identified in the intron 1 of the KISSI gene of all three goat breeds. The three goat breeds were in Hardy-Weinberg disequilibrium at g.2124T $>$ A and g.2270C $>$ T loci. The g.2124T $>A$ and g. $2270 \mathrm{C}>\mathrm{T}$ loci were closely linked in the three goat breeds $\left(r^{2}>0.33\right)$. The g.2124T $>$ A and g.2270C $>$ T SNPs were significantly associated with litter size, and the $\mathrm{C} 1$ female goats had a larger litter size than did those with the other genotypes. These results extend the spectrum
\end{abstract}


of genetic variation of the goat KISS1 gene, which contributes to our knowledge of goat genetic resources for breeding programs.

Key words: Combined genotype; SNP; PCR-RFLP; Goat

\section{INTRODUCTION}

In livestock, litter size is the result of well-regulated interactions of endocrine and paracrine mediators. Genetic information, particularly for those loci that affect performance traits, is an important tool in breeding programs. Extensive research has been carried out on different prolific goat breeds to identify the genes involved in the control of litter size (Polley et al., 2009). Several candidate genes and their relationship with litter size in goats have been studied, such as the G protein-coupled receptor 54 (GPR54) gene (Cao et al., 2011), cocaine-amphetamine-regulated transcript (CART) gene (Wang et al., 2011), kit ligand $(K I T L G)$ gene (An et al., 2012), bone morphogenetic protein receptor IB (BMPR-IB) gene (Chu et al., 2010) and so on.

The KISS1 gene encodes a family of neuropeptides called kisspeptins, which activate receptor $\mathrm{G}$ protein-coupled receptor-54 and play a role in the neuroendocrine regulation of GnRH secretion (Smith et al., 2005). Moreover, KISS1 neurons in the hypothalamus participate in crucial features of reproductive maturation and function, such as brain-level sex differentiation, puberty onset and the neuroendocrine regulation of gonadotropin secretion and ovulation (Caraty et al., 2010). Kisspeptins are very potent elicitors of luteinizing hormone (LH) and follicle-stimulating hormone (FSH) secretion in different mammalian species (Gottsch et al., 2004; Dhillo et al., 2005). Specifically in the female, the hypothalamic KISS1/ GPR54 system seems to operate as a central conduit for not only the negative but also the positive feedback regulation of gonadotropins, thereby playing a substantial role in the generation of the preovulatory surge of LH (Kinoshita et al., 2005; Smith et al., 2006). In sheep, KISS1 mRNA-expressing cells are found in the arcuate nucleus (ARC) and dorsallateral preoptic area, and both appear to mediate the positive feedback effect of estradiol to generate the preovulatory $\mathrm{GnRH} / \mathrm{LH}$ surge (Smith et al., 2011). In addition to their prominent expression at hypothalamic levels, fragmentary evidence suggests that KISS1 andor KISS1R mRNAs or proteins are also present in several peripheral reproductive tissues including the ovarie (de Roux et al., 2003), oviducts (Gaytan et al., 2007) and testes (Ohtaki et al., 2001). In good agreement, kisspeptin immunoreactivity has been observed in cycling human and marmoset ovaries, with prominent signals in the theca layer of growing follicles, corpora lutea, interstitial gland and ovarian surface epithelium (Gaytan et al., 2009). KISS1 knockout mice are viable and healthy with no apparent abnormalities but fail to undergo sexual maturation. Mutant female mice do not progress through the estrous cycle (d'Anglemont de Tassigny et al., 2007). One novel nonsynonymous single nucleotide polymorphism (G54650055T) substituting one amino acid in kisspeptin (P110T) has been found to be statistically related to central precocious puberty in human (Luan et al., 2007). These findings indicate that the KISS1 gene could be an excellent candidate gene for reproductive traits in humans and livestock. In view of the above considerations, the objectives of the present study were to determine the polymorphisms of the caprine KISS1 gene in three breeds and to investigate the associations between these genetic markers and litter size. 


\section{MATERIAL AND METHODS}

\section{Genomic DNA isolation and data collections}

Blood samples were obtained from 723 goats belonging to three breeds: Xinong Saanen (SN; $N=306$ ), Guanzhong (GZ; N = 221) and Boer (BG; $N=196)$. They were reared in Qianyang, Zhouzhi and Liuyou counties of Shaanxi Province, respectively. All diets were based on alfalfa, corn silage, and a combination of concentrates including corn, soybean meal, and bone meal. Health, fertility and production records were maintained by the dairymen and veterinarians. The litter size from the first to fourth parity was obtained from production records. Five milliliters blood per goat were collected aseptically from the jugular vein and kept in a tube containing ACD anticoagulant (citric acid, sodium citrate and dextrose - 10:27:38). All samples were delivered to the laboratory in an ice box. The genomic DNA was extracted from white blood cells using a standard phenol-chloroform extraction protocol. All experiments were performed in accordance with the National Institute of Health Guide for the Care and Use of Laboratory Animals.

\section{Cloning and sequencing of KISS1 promoter}

Using the Primer software (version 6.0) and according to the bovine KISSI gene (GenBank accession No. NW_003104427.1), one pair of primers was designed to amplify the goat KISS1 promoter (Table 1). The PCR products were separated on a $1.5 \%$ agarose gel, purified with the Gel Extraction kit (Tiangen, Beijing, China) and inserted into pMD19-T vector (TaKaRa, Dalian, China), according to provided protocols. The recombinant plasmid was then transformed into competent Escherichia coli JM109 cells. At least three positive clones were sequenced in both directions by Beijing Invitrogen Biotechnology Co. Ltd. (Beijing, China). Sequence analysis was performed with on-line BLAST, http://zeus2.itb.cnr. it/ w webgene/wwwHC_tata.html and http://www.cbrc.jp/research/db/TFSEARCH.

\begin{tabular}{|c|c|c|c|c|c|}
\hline Primer & Sequence $\left(5^{\prime} \rightarrow 3^{\prime}\right)$ & Gene region & Amplicon (bp) & GenBank accession No. & $\operatorname{Tm}\left({ }^{\circ} \mathrm{C}\right)$ \\
\hline KISS1-F1 & TTCACCTGGCTGACTTGT & Promoter & 2069 & NW_003104427.1 & 57 \\
\hline KISS1-R1 & ATACCTGTGGTTCTAGGATTC & & & & \\
\hline KISS1-F2 & TGCAAAGCCGAGTGTGCAGG & Exon 1 & 594 & GU142847 & 65 \\
\hline KISS1-R2 & TGAAGGCGGTGGCACAAAGG & & & & \\
\hline KISS1-F3 & CCCGCTGTAACTAGAGAAAG & Intron 1 & 377 & GU142847 & 51 \\
\hline KISS1-R3 & CATCCAGGGTGAGTGATACT & & & & \\
\hline
\end{tabular}

$\mathrm{Tm}=$ melting temperature.

\section{SNP investigation and genotyping}

On the basis of the caprine KISS1 gene sequence (GenBank accession No. GU142847), two pairs of primers were designed to amplify the exon 1 and partial intron 1 of the KISSI gene (Table 1). Their optimal annealing temperatures are shown in Table 1. Herein, we screened them to identify SNPs of this gene by the pooled DNA sequencing method (Bansal et al., 2002). Five microliters $100 \mathrm{ng} / \mu \mathrm{L}$ DNA per sample were collected to create a DNA pool for each goat breed. 
PCR products were sent to Beijing Genomics Institute (Beijing, China) to be sequenced in both directions. SNPs were detected using Chromas 2.31 and DNAstar 7.0 softwares.

The SNPs of the KISS1 gene were genotyped by polymerase chain reaction-restriction fragment length polymorphism (PCR-RFLP). The $25-\mu \mathrm{L}$ reaction volume contained $50 \mathrm{ng}$ genomic DNA, $12.5 \mu \mathrm{L} 2 \mathrm{X}$ reaction mix (including $500 \mu \mathrm{M}$ dNTPs, $20 \mathrm{mM}$ Tris-HCl, $\mathrm{pH}$ 9, $100 \mathrm{mM} \mathrm{KCl}, 3 \mathrm{mM} \mathrm{MgCl} 2), 0.5 \mu \mathrm{M}$ of each primer, and $0.5 \mathrm{U}$ Taq DNA polymerase. The cycling protocol was $5 \mathrm{~min}$ at $95^{\circ} \mathrm{C}$ and 35 cycles of denaturation at $94^{\circ} \mathrm{C}$ for $30 \mathrm{~s}$, annealing at $\mathrm{X}^{\circ} \mathrm{C}$ (Table 1) for $30 \mathrm{~s}$, and extension at $72^{\circ} \mathrm{C}$ for $35 \mathrm{~s}$, with a final extension at $72^{\circ} \mathrm{C}$ for 10 min. PCR products $(5 \mu \mathrm{L})$ of different primer pairs were mixed with $0.7 \mu \mathrm{L} 10 \mathrm{X}$ buffer, 2.5 $\mathrm{U}$ restriction enzyme (NEB, Ipswich, UK) and $3.8 \mu \mathrm{L}$ sterile $\mathrm{ddH}_{2} \mathrm{O}$, and then incubated for $1.5 \mathrm{~h}$ at $37^{\circ} \mathrm{C}$. The restriction enzymes used are shown in Table 2 . Digestion products were subjected to $3.5 \%$ horizontal agarose gel electrophoresis. The agarose gels were stained with ethidium bromide, and the genotypes were then determined.

\section{Statistical analysis}

Allelic frequencies, heterozygosity $\left(H_{\mathrm{E}}\right)$ and polymorphism information content (PIC) were calculated using Popgene (version 4.0). Linkage disequilibrium (LD) was assessed by the SHEsis software (Shi and He, 2005). Statistical analysis was performed using the general linear model procedure of the SPSS 16 statistical software. The model applied was: $Y_{\mathrm{iklm}}=\mu+C_{\mathrm{i}}+B_{\mathrm{k}}$ $+(B C)_{\mathrm{ik}}+S_{1}+E_{\mathrm{iklm}}$, where $Y_{i k l m}$ is the trait measured on each of the $i k l m^{\text {th }}$ animal, $\mu$ is the overall population mean, $C_{i}$ is the fixed effect associated with the $i^{\text {th }}$ combined genotype, $B_{k}$ is the fixed effect associated with the $k^{\text {th }}$ breed, $(B C)_{i k}$ is the interaction between the $i^{\text {th }}$ combined genotype and the $k^{\text {th }}$ breed, $S_{l}$ is the fixed effect associated with the $l^{\text {th }}$ sire, and $E_{i k l m}$ is the random error.

\section{RESULTS}

\section{SNP identification and genotypes}

The 2069-bp fragment, including a 1962-bp fragment upstream from the start codon and a 107-bp fragment of exon 1 in the goat KISS1 gene, was amplified (Figure 1). The sequence of the KISS1 promoter was submitted to the National Center for Biotechnology Information (GenBank accession No. JX047312). A comparison with the bovine KISS1 5'-flanking sequence demonstrated a high degree of homology with approximately $88.59 \%$ nucleotide identity. The transcription factor binding sites of the KISS1 promoter region are shown in Figure S1. Six TATA boxes were found in the KISS1 promoter region (TCTATCACTG, CTGATACCAT, GGTCTATAGC, TCTATAGCTC, ATTATAGGCA, and ACTATATGGC) (Figure S1). Two SNPs (g.2124T >A and g.2270C $>$ T) were genotyped in the three goat breeds (Figures 2 and 3). The g.2124T $>$ A and g.2270C $>$ T mutations were in intron 1 (GenBank accession No. JQ806381). At g.2124T >A and g.2270C $>$ T loci, PIC was 0.36-0.37 in the three goat breeds. According to the PIC classification (low polymorphism if PIC value $<0.25$, moderate polymorphism if $0.25<$ PIC value $<0.50$, and high polymorphism if PIC $>0.50$ ), the goat breeds had moderate genetic diversity at g.2124T $>$ A and g.2270C $>$ T loci. Genotypic and allelic frequencies of the two SNPs are shown in Table 2. The SN and GZ breeds were in Hardy-Weinberg disequilibrium at the g.2124T $>$ A and g.2270C $>$ T loci $(\mathrm{P}<0.05)$ (Table 2). 
LD was estimated in these breeds to determine the linkage relationships between the two SNPs (Table 2). If $r^{2}>0.33$, LD was considered strong (Ardlie et al., 2002). According to the results, both g.2124T $>$ A and g.2270C $>$ T loci were closely linked in the three goat breeds (Table 2).

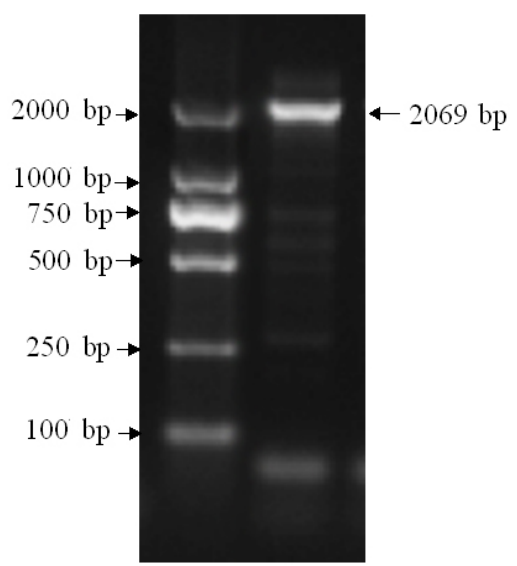

Figure 1. PCR product of the promoter region of the goat KISS1 gene.

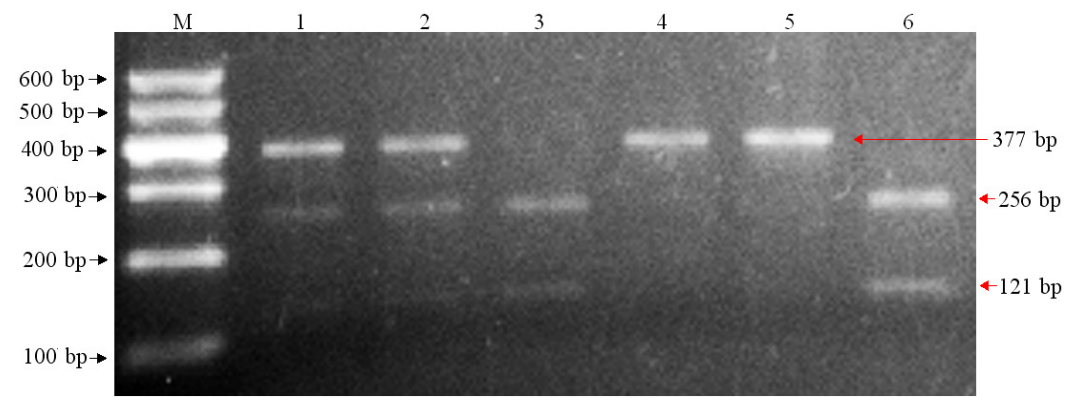

Figure 2. Electrophoresis patterns obtained after digestion with $X m n \mathrm{I}$ endonuclease at the g.2124T $>$ A locus. Lane $M=$ DNA marker; lanes 1 and $2=$ TA genotype; lanes 3 and $6=$ TT genotype; lanes 4 and $5=$ AA genotype

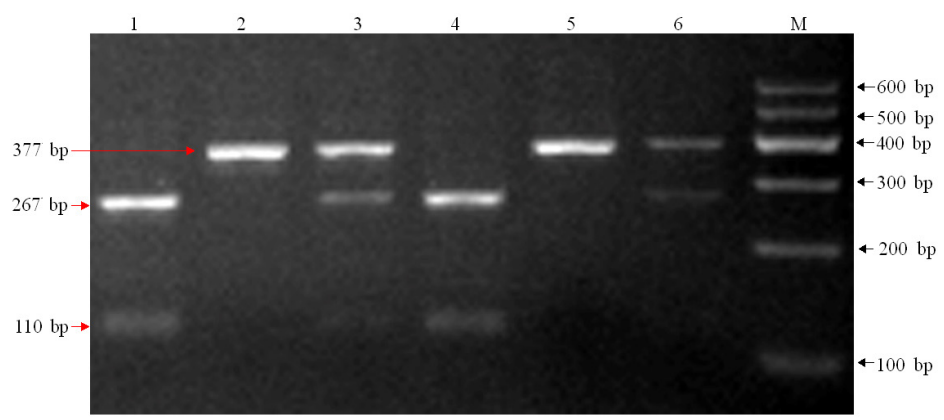

Figure 3. Electrophoresis patterns obtained after digestion with $\mathrm{MwoI}$ endonuclease at the g. $2270 \mathrm{C}>\mathrm{T}$ locus. Lane $M=$ DNA marker; lanes 1 and $4=\mathrm{CC}$ genotype; lanes 2 and $5=\mathrm{TT}$ genotype; lanes 3 and $6=\mathrm{TC}$ genotype. 


\begin{tabular}{|c|c|c|c|c|c|c|}
\hline \multirow[t]{2}{*}{ Locus } & \multirow[t]{2}{*}{ Restriction enzyme } & & & \multicolumn{3}{|c|}{ Breed } \\
\hline & & & & SN & GZ & BG \\
\hline \multirow[t]{8}{*}{ g. $2124 \mathrm{~T}>\mathrm{A}$} & $\mathrm{XmnI}$ & Genotype & $\mathrm{TT}$ & 118 & 85 & 66 \\
\hline & & & $\mathrm{TA}$ & 129 & 91 & 82 \\
\hline & & & AA & 59 & 45 & 48 \\
\hline & & Allele & $\mathrm{T}$ & 0.60 & 0.59 & 0.55 \\
\hline & & & $\mathrm{A}$ & 0.40 & 0.41 & 0.45 \\
\hline & & $\mathrm{H}_{\mathrm{E}}$ & & 0.42 & 0.41 & 0.42 \\
\hline & & PIC & & 0.36 & 0.37 & 0.37 \\
\hline & & Equilibrium $\chi^{2}$ test & & $\mathrm{P}=0.03$ & $\mathrm{P}=0.03$ & $\mathrm{P}=0.02$ \\
\hline \multirow[t]{8}{*}{ g. $2270 \mathrm{C}>\mathrm{T}$} & MwoI & Genotype & $\mathrm{TT}$ & 122 & 86 & 81 \\
\hline & & & $\mathrm{TC}$ & 125 & 89 & 87 \\
\hline & & & $\mathrm{CC}$ & 59 & 46 & 28 \\
\hline & & Allele & $\mathrm{T}$ & 0.60 & 0.59 & 0.64 \\
\hline & & & $\mathrm{C}$ & 0.40 & 0.41 & 0.36 \\
\hline & & $\mathrm{H}_{\mathrm{E}}$ & & 0.41 & 0.40 & 0.44 \\
\hline & & PIC & & 0.36 & 0.37 & 0.36 \\
\hline & & Equilibrium $\chi^{2}$ test & & $\mathrm{P}=0.01$ & $\mathrm{P}=0.01$ & $\mathrm{P}=0.55$ \\
\hline LD of g. $2124 \mathrm{~T}>\mathrm{A}$ and g. $2270 \mathrm{C}>\mathrm{T}$ & & $r^{2}$ & & $0.63^{\mathrm{a}}$ & $0.71^{\mathrm{a}}$ & $0.52^{\mathrm{a}}$ \\
\hline
\end{tabular}

\section{Association and effects of combined genotypes}

The associations of 7 combined genotypes of 2 loci with litter size are shown in Table 3. In the first parity, the $\mathrm{C} 1$ female goats had greater litter size than did the $\mathrm{C} 4, \mathrm{C} 6$ or $\mathrm{C} 7$ goats $(\mathrm{P}<0.05)$. In the second and third parity, the $\mathrm{C} 1$ female goats had larger litter size than did the $\mathrm{C} 7$ goats $(\mathrm{P}<0.05)$. In the average parity, the $\mathrm{C} 7$ female goats had the smallest litter size compared to the $\mathrm{C} 1$ and $\mathrm{C} 4$ goats $(\mathrm{P}<0.05)$, and the $\mathrm{C} 1$ female goats had larger litter size compared to the $\mathrm{C} 4$ goats $(\mathrm{P}<0.05)$.

Table 3. Combined effect of two SNP loci on litter size (means \pm standard errors) in SN, GZ and BG breeds.

\begin{tabular}{|c|c|c|c|c|c|c|}
\hline Genotype & $\mathrm{N}$ & $\begin{array}{l}\text { 1st parity } \\
\text { litter size }\end{array}$ & $\begin{array}{l}\text { 2nd parity } \\
\text { litter size }\end{array}$ & $\begin{array}{l}\text { 3rd parity } \\
\text { litter size }\end{array}$ & $\begin{array}{l}\text { 4th parity } \\
\text { litter size }\end{array}$ & $\begin{array}{l}\text { Average } \\
\text { litter size }\end{array}$ \\
\hline C1 (TTTT) & 209 & $1.55 \pm 0.05^{\mathrm{b}}$ & $1.85 \pm 0.05^{\mathrm{b}}$ & $1.98 \pm 0.05^{\mathrm{b}}$ & $2.08 \pm 0.06$ & $1.86 \pm 0.03^{b}$ \\
\hline C2 (TATT) & 29 & $1.44 \pm 0.11$ & $1.80 \pm 0.11$ & $1.72 \pm 0.12$ & $1.99 \pm 0.12$ & $1.74 \pm 0.06$ \\
\hline C3 (TTTC) & 23 & $1.28 \pm 0.12$ & $1.67 \pm 0.12$ & $1.76 \pm 0.12$ & $2.23 \pm 0.13$ & $1.73 \pm 0.07$ \\
\hline C4 (TATC) & 221 & $1.40 \pm 0.05^{\mathrm{a}}$ & $1.73 \pm 0.05$ & $1.94 \pm 0.05^{\mathrm{b}}$ & $2.02 \pm 0.06$ & $1.77 \pm 0.03^{\mathrm{c}}$ \\
\hline C5 (AATC) & 26 & $1.29 \pm 0.16$ & $1.89 \pm 0.16$ & $1.95 \pm 0.16$ & $1.92 \pm 0.17$ & $1.76 \pm 0.09$ \\
\hline C6 (TACC) & 22 & $1.16 \pm 0.12^{\mathrm{a}}$ & $1.61 \pm 0.13$ & $1.94 \pm 0.13$ & $2.02 \pm 0.14$ & $1.68 \pm 0.07$ \\
\hline C7 (AACC) & 100 & $1.31 \pm 0.06^{\mathrm{a}}$ & $1.60 \pm 0.06^{\mathrm{a}}$ & $1.70 \pm 0.07^{\mathrm{a}}$ & $1.97 \pm 0.07$ & $1.64 \pm 0.04^{\mathrm{a}}$ \\
\hline
\end{tabular}

Values with different superscripts in the same column differ significantly at $\mathrm{P}<0.05$. For breed abbreviations, see legend to Table 2 .

\section{DISCUSSION}

CdxA, CEPB, GATA-1, Sp1, and MZF1 play an important role in regulating gene expression (Grange et al., 1991; Merika and Orkin, 1993; Cram et al., 2001; Liu et al., 2011), which can also be observed in the goat KISS1 promoter. In addition, TATA boxes (ATTATAGGCA and ACTATATGGC) were found in the goat and bovine KISS1 promoters. 
Therefore, they may play a similar regulatory role in both cattle and goats. Both g.2124T $>$ A and g. 2270C $>$ T loci were closely linked in the three goat breeds studied, which may be a result of selection. Selection during domestication and improvement can influence the LD level of a gene (Saunders et al., 2005), and selection aimed at alleles of a structural gene can significantly increase the LD level in the target gene region (Clark et al., 2004). The two SNP loci were in Hardy-Weinberg disequilibrium in the SN and GZ breeds $(\mathrm{P}<0.05)$, which showed that the genotypic frequencies had been affected by selection, mutation or migration. So far, there have been some studies of the KISS1 gene as a candidate gene for reproductive traits in animals, which revealed that the KISS1 gene plays an important role in animal reproduction (Tomikawa et al., 2010). Huijbregts et al. (2012) detected three SNPs (c.638insT, c.641C $>\mathrm{G}$ and c.645G $>\mathrm{CA}$ ) in the 3'-UTR of the human KISS1 gene, and found that the c.645G>CA mutation was associated with central precocious puberty. Cao et al. (2010) showed an association between allele C of the 296 locus and allele deletion of the 1960-1977 locus in the KISS1 gene and larger litter size in Jining Grey goats. Hou et al. (2011) identified T2643C and 8-bp base deletions (2677AGTTCCCC) in intron 2 of the goat KISS1 gene, with T2643C showing significant effects on litter size $(\mathrm{P}<0.05)$. Reproductive traits are complex quantitative traits involving multiple genes, loci and interactions, so it is important to analyze the combined effect of multiple genes or loci on reproductive traits. In the present study, the association between multiple loci and litter size from the first to the fourth parity was analyzed. The $\mathrm{C} 1$ female goats had larger litter size compared to those with other combined genotypes in average parity. Although two novel variants of the KISS1 gene do not concern the coding region, it is possible that they regulate the expression of the KISS1 gene. Sequences in the non-coding region can affect the mechanism of mRNA deadenylation and degradation (Xu et al., 1997; Nackley et al., 2006). Accumulating evidence further shows that central or peripheral administration of kisspeptin stimulates GnRH-dependent LH and FSH secretion in various mammalian species from rodents to humans (Gottsch et al., 2004; Navarro et al., 2005), suggesting that kisspeptin plays an essential role in governing reproductive functions throughout species. Biochemical and physiological functions, together with the results obtained in our study, indicate that the KISS1 gene could be used as a molecular breeding marker in goats.

In conclusion, this study indicated that two SNPs may play an important role in litter size. The $\mathrm{C} 1$ female goats had a larger litter size than did those with other combined genotypes in average parity and could be used for the development of new breeds of prolific goats.

\section{ACKNOWLEDGMENTS}

Research supported by the National Support Program of China (\#2011BAD28B05-3) and the Science and Technology Innovation Project of Shaanxi Province (\#2011KTCL02-09).

\section{Supplementary material}

\section{REFERENCES}

An XP, Hou JX, Li G, Song YX, et al. (2012). Polymorphism identification in the goat KITLG gene and association analysis with litter size. Anim. Genet. 43: 104-107.

Ardlie KG, Kruglyak L and Seielstad M (2002). Patterns of linkage disequilibrium in the human genome. Nat. Rev. Genet. 3: 299-309. 
Bansal A, van den Boom D, Kammerer S, Honisch C, et al. (2002). Association testing by DNA pooling: an effective initial screen. Proc. Natl. Acad. Sci. U. S. A. 99: 16871-16874.

Cao GL, Chu MX, Fang L, Di R, et al. (2010). Analysis on DNA sequence of KiSS-1 gene and its association with litter size in goats. Mol. Biol. Rep. 37: 3921-3929.

Cao GL, Chu MX, Fang L, Feng T, et al. (2011). Analysis on DNA sequence of GPR54 gene and its association with litter size in goats. Mol. Biol. Rep. 38: 3839-3848.

Caraty A, Franceschini I and Hoffman GE (2010). Kisspeptin and the preovulatory gonadotrophin-releasing hormone/ luteinising hormone surge in the ewe: basic aspects and potential applications in the control of ovulation. $J$. Neuroendocrinol. 22: 710-715.

Chu MX, Zhao XH, Zhang YJ, Jin M, et al. (2010). Polymorphisms of BMPR-IB gene and their relationship with litter size in goats. Mol. Biol. Rep. 37: 4033-4039.

Clark RM, Linton E, Messing J and Doebley JF (2004). Pattern of diversity in the genomic region near the maize domestication gene tb1. Proc. Natl. Acad. Sci. U. S. A. 101: 700-707.

Cram EJ, Liu BD, Bjeldanes LF and Firestone GL (2001). Indole-3-carbinol inhibits CDK6 expression in human MCF-7 breast cancer cells by disrupting Sp1 transcription factor interactions with a composite element in the CDK6 gene promoter. J. Biol. Chem. 276: 22332-22340.

d'Anglemont de Tassigny, X, Fagg LA, Dixon JP, Day K, et al. (2007). Hypogonadotropic hypogonadism in mice lacking a functional Kiss 1 gene. Proc. Natl. Acad. Sci. U. S. A. 104: 10714-10719.

de Roux N, Genin E, Carel JC, Matsuda F, et al. (2003). Hypogonadotropic hypogonadism due to loss of function of the KiSS1-derived peptide receptor GPR54. Proc. Natl. Acad. Sci. U. S. A. 100: 10972-10976.

Dhillo WS, Chaudhri OB, Patterson M, Thompson EL, et al. (2005). Kisspeptin-54 stimulates the hypothalamic-pituitary gonadal axis in human males. J. Clin. Endocrinol. Metab. 90: 6609-6615.

Gaytan F, Gaytan M, Castellano JM, Romero M, et al. (2009). KiSS-1 in the mammalian ovary: distribution of kisspeptin in human and marmoset and alterations in KiSS-1 mRNA levels in a rat model of ovulatory dysfunction. Am. J. Physiol. Endocrinol. Metab. 296: E520-E531.

Gaytan M, Castellano JM, Roa J, Sanchez-Criado JE, et al. (2007). Expression of KiSS-1 in rat oviduct: possible involvement in prevention of ectopic implantation? Cell Tissue Res. 329: 571-579.

Gottsch ML, Cunningham MJ, Smith JT, Popa SM, et al. (2004). A role for kisspeptins in the regulation of gonadotropin secretion in the mouse. Endocrinology 145: 4073-4077.

Grange T, Roux J, Rigaud G and Pictet R (1991). Cell-type specific activity of two glucocorticoid responsive units of rat tyrosine aminotransferase gene is associated with multiple binding sites for $\mathrm{C} / \mathrm{EBP}$ and a novel liver-specific nuclear factor. Nucleic Acids Res. 19: 131-139.

Hou JX, An XP, Wang JG and Song YX (2011). New genetic polymorphisms of KiSS- 1 gene and their association with litter size in goats. Small Rumin. Res. 96: 106-110.

Huijbregts L, Roze C, Bonafe G, Houang M, et al. (2012). DNA polymorphisms of the KiSS1 3' untranslated region interfere with the folding of a G-rich sequence into G-quadruplex. Mol. Cell Endocrinol. 351: 239-248.

Kinoshita M, Tsukamura H, Adachi S, Matsui H, et al. (2005). Involvement of central metastin in the regulation of preovulatory luteinizing hormone surge and estrous cyclicity in female rats. Endocrinology 146: 4431-4436.

Liu YF, Zan LS, Cui WT, Xin YP, et al. (2011). Molecular cloning, characterization and association analysis of the promoter region of the bovine CDK6 gene. Genet. Mol. Res. 10: 1777-1786.

Luan X, Zhou Y, Wang W, Yu H, et al. (2007). Association study of the polymorphisms in the KISS1 gene with central precocious puberty in Chinese girls. Eur. J. Endocrinol. 157: 113-118.

Merika M and Orkin SH (1993). DNA-binding specificity of GATA family transcription factors. Mol. Cell Biol. 13: 39994010.

Nackley AG, Shabalina SA, Tchivileva IE, Satterfield K, et al. (2006). Human catechol-O-methyltransferase haplotypes modulate protein expression by altering mRNA secondary structure. Science 314: 1930-1933.

Navarro VM, Castellano JM, Fernandez-Fernandez R, Tovar S, et al. (2005). Characterization of the potent luteinizing hormone-releasing activity of KiSS-1 peptide, the natural ligand of GPR54. Endocrinology 146: 156-163.

Ohtaki T, Shintani Y, Honda S, Matsumoto H, et al. (2001). Metastasis suppressor gene KiSS-1 encodes peptide ligand of a G-protein-coupled receptor. Nature 411: 613-617.

Polley S, De Sachinandan, Batabyal S, Kaushik R, et al. (2009). Polymorphism of fecundity genes (BMPR1B, BMP15 and GDF9) in the Indian prolific Black Bengal goat. Small Rumin. Res. 85: 122-129.

Saunders MA, Slatkin M, Garner C, Hammer MF, et al. (2005). The extent of linkage disequilibrium caused by selection on G6PD in humans. Genetics 171: 1219-1229.

Shi YY and He L (2005). SHEsis, a powerful software platform for analyses of linkage disequilibrium, haplotype construction, and genetic association at polymorphism loci. Cell Res. 15: 97-98. 
Smith JT, Cunningham MJ, Rissman EF, Clifton DK, et al. (2005). Regulation of Kiss 1 gene expression in the brain of the female mouse. Endocrinology 146: 3686-3692.

Smith JT, Popa SM, Clifton DK, Hoffman GE, et al. (2006). Kiss1 neurons in the forebrain as central processors for generating the preovulatory luteinizing hormone surge. J. Neurosci. 26: 6687-6694.

Smith JT, Li Q, Yap KS, Shahab M, et al. (2011). Kisspeptin is essential for the full preovulatory LH surge and stimulates GnRH release from the isolated ovine median eminence. Endocrinology 152: 1001-1012.

Tomikawa J, Homma T, Tajima S, Shibata T, et al. (2010). Molecular characterization and estrogen regulation of hypothalamic KISS1 gene in the pig. Biol. Reprod. 82: 313-319.

Wang PQ, Deng LM, Zhang BY, Chu MX, et al. (2011). Polymorphisms of the cocaine-amphetamine-regulated transcript (CART) gene and their association with reproductive traits in Chinese goats. Genet. Mol. Res. 10: 731-738.

Xu N, Chen CY and Shyu AB (1997). Modulation of the fate of cytoplasmic mRNA by AU-rich elements: key sequence features controlling mRNA deadenylation and decay. Mol. Cell Biol. 17: 4611-4621. 